\title{
Kontak Antarkelompok dan Demografi sebagai Prediktor Prasangka Etnis Sunda terhadap Etnis Tionghoa
}

\author{
Gusvira Noerwendayah Sudiana ${ }^{(1)}, \operatorname{Helli~Ihsan}^{(2)}$, Gemala Nurendah $^{(3)}$ \\ ${ }^{(1),(2),(3)}$ Departemen Psikologi, Fakultas Ilmu Pendidikan, Universitas Pendidikan Indonesia, \\ Bandung, Indonesia
}

\begin{abstract}
In this research, we aimed to examine the role of intergroup contact and demographic factors, as well as that of the interaction between the two variables in explaining prejudice against Chinese among a sample of Sundanese in Bandung. Participants were 384 Sundanese currently living in Bandung. Designed as a correlational study, our work revealed that, first, intergroup contacts significantly and negatively predicted prejudice against Chinese. Second, age and gender significantly predicted prejudice. The final finding demonstrated that, not in line with the hypothesis specified, demographic factors did not significantly moderate the relationship between intergroup contacts and prejudice. We close by elaborating the theoretical and practical implications of those empirical findings in the discussion section, which also explains some limitations in this research and recommendations for follow-up studies to address the limitations.
\end{abstract}

Keywords: Chinese, intergroup contact, prejudice, Sundanese

Penelitian ini bertujuan untuk menguji peran kontak antarkelompok dan faktor-faktor demografis serta interaksi antar keduanya dalam menjelaskan prasangka etnis Sunda terhadap etnis Tionghoa di Bandung. Subjek penelitian adalah 384 etnis Sunda yang tinggal di Bandung. Penelitian ini dirancang sebagai studi korelasional, yang hasilnya menunjukkan bahwa, pertama, kontak antarkelompok berperan signifikan dalam memprediksi ke arah negatif prasangka terhadap etnis Tionghoa. Hasil kedua menunjukkan bahwa usia dan jenis kelamin juga berperan signifikan dalam menjelaskan prasangka. Temuan terakhir menunjukkan bahwa, tidak mendukung hipotesis yang ditetapkan, faktor-faktor demografis tidak berperan signifikan dalam memoderasi hubungan antara kontak antarkelompok dan prasangka terhadap etnis Tionghoa. Implikasi teoritis dan praktis temuan-temuan empiris tersebut dielaborasi di bagian diskusi, yang juga menjelaskan sejumlah kekurangan dalam penelitian ini serta rekomendasi studi lanjutan untuk menutupi kekurangan tersebut.

Kata kunci: kontak antarkelompok, etnis Sunda, etnis Tionghoa, prasangka

MEDIAPSI, 2020, Vol. 6(2), 145-156, DOI: https://doi.org/10.21776/ub.mps.2020.006.02.8

Received: 03-10-2020. Revised: 23-10-2020. Accepted: 07-11-2020. Published online: 07-12-2020

Handling Editor: Esti Zaduqisti, IAIN Pekalongan, Pekalongan, Indonesia

*Corresponding author Gusvira Noerwendayah Sudiana, Departemen Psikologi, Fakultas Ilmu Pendidikan, Universitas Pendidikan Indonesia, Bandung, Indonesia. E-mail: gusviranoerwen@ gmail.com

This work is licensed under a Creative Commons Attribution-NonCommercial 4.0 International License.

How to cite this article in accordance with the American Psychological Association (APA) $6^{\text {th }}$ guidelines:

Sudiana, G, N., Ihsan, H., \& Nurendah, G. (2020). Kontak antarkelompok dan demografi sebagai prediktor prasangka etnis Sunda terhadap etnis Tionghoa. MEDIAPSI, 6(2), 145-156. https://doi.org/10.21776/ub.mps.2020.006.02.8

\section{Pendahuluan}

Etnis Tionghoa dikenal sebagai salah satu kelompok minoritas yang tinggal di Indonesia (Ikasari, 2017; Melissa, 2013; Suryadinata, 2003). Masuknya etnis Tionghoa ke wilayah
Indonesia terjadi sejak masa sebelum penjajahan Belanda (Kustedja, 2012). Awalnya, etnis Tionghoa menjalin relasi dengan warga pribumi sebagai mitra dagang. Namun. Ketika Belanda datang, VOC memanfaatkan 
kemampuan yang dimiliki oleh etnis Tionghoa dan memberikannya hak istimewa. Hal tersebut merupakan asal-usul munculnya kebencian warga pribumi terhadap etnis Tionghoa (Coppel, 2003).

Berbagai konflik yang terjadi sejak zaman penjajahan hingga orde baru banyak menjadikan etnis Tionghoa sebagai target penyerangan (Isnaeni, 2019). Konflik-konflik tersebut terjadi di berbagai daerah di Indonesia, misalnya kerusuhan pada Mei 1998 yang berpusat di Jakarta, Medan, dan Surakarta (Lestari, 2018) kerusuhan anti Tionghoa tahun 1980 di Semarang (Wigarani, Bain, \& Witasari 2019), dan kerusuhan pada Mei 1963 di Bandung (Sjafari, 2018). Masing-masing konflik memberikan dampak yang ekstrem, seperti penyerangan terhadap bangunan milik etnis Tionghoa dan pembunuhan.

Sebelum kerusuhan Mei 1998 yang merupakan puncak dari konflik berkepanjangan akibat kebencian terhadap etnis Tionghoa, kerusuhan yang terjadi di Bandung sempat terulang kembali setelah peristiwa pertama pada tahun 1963, yakni pada 5 Agustus 1973. Peristiwa tersebut disebabkan oleh insiden pemukulan terhadap salah satu anggota etnis Sunda yang membuat warga marah dan melakukan penyerangan pada etnis Tionghoa di Bandung (Muhammad \& Larasati, 2017). Sjamsuddin (2002) menjelaskan, kerusuhan itu dilatarbelakangi oleh stereotip tentang etnis Tionghoa, seperti anggapan bahwa etnis Tionghoa seringkali menghalangi usaha pribumi untuk mencapai kesejahteraan ekonomi, serta pandangan yang menggambarkan etnis Tionghoa sebagai warga negara asing di Indonesia. Kondisi demikian mengakibatkan munculnya prasangka yang cukup kuat, sehingga peristiwa tahun 1973 dikategorikan sebagai pengulangan dari kerusuhan tahun 1963 di Bandung karena latar belakang masalah yang sama. Himawan (2020) mengemukakan, peristiwa sejarah dan stereotip yang bertahan menjadi faktor munculnya prasangka terhadap etnis Tionghoa hingga saat MEDIAPSI | 2020. Vol. 6, No. 2, 145-156 ini.

Srisayekti, Setiady, dan Sanitioso (2015) menyatakan bahwa prasangka yang muncul pada etnis Sunda terhadap etnis Tionghoa dilatarbelakangi stereotip yang dipersepsikan dapat mengancam harga diri etnis Sunda sebagai kelompok mayoritas di Bandung. Pernyataan tersebut sejalan dengan penelitian Burhan dan Sani (2013), yang menjelaskan bahwa prasangka timbul sebagai reaksi terhadap ancaman, baik yang bersifat simbolik (nilai, budaya, moral) atau realistik (kesejahteraan hidup, yang meliputi kekuatan politik dan ekonomi). Selain anggapan bahwa etnis Tionghoa bukan warga negara asli Indonesia, persepsi mengenai ancaman tersebut memengaruhi prasangka etnis Sunda sebagai kelompok mayoritas terutama terhadap etnis Tionghoa dibandingkan etnis lain di Bandung (Dhani, 2016; Srisayekti dkk., 2015; Sjamsuddin, 2002).

Allport (1954) menyatakan, prasangka dapat membuat seseorang atau kelompok memandang kelompok lain secara negatif berdasarkan pemikiran yang tidak rasional. Kemudian, prasangka berhubungan dengan diskriminasi yang berpotensi menghalangi orang lain untuk mendapatkan hak yang sama di lingkungan sosial (Adelina, 2017; Cohrs \& Duckitt, 2012; Schutz \& Six, 1996). Beberapa penelitian terdahulu menemukan bahwa prasangka dapat menyebabkan konflik sosial, mulai dari skala kecil seperti perkelahian, hingga skala besar seperti konflik antaretnis yang melibatkan aksi pengusiran bahkan pembantaian terhadap kelompok yang menjadi target prasangka (Allport, 1954; Bobo \& Licari, 1989).

Di sisi lain, secara psikologis, orang yang menjadi target prasangka akan mengalami peningkatan stres karena merasa terancam oleh keberadaan kelompok yang menjadi pelaku prasangka sehingga hal tersebut mengganggu kualitas kesehatan mentalnya (Tropp, 2003; Sawyer, Major, Casad, Townsend, \& Mendes, 2012). Pettigrew dan Tropp

(2006) 
menjelaskan, jika suatu kelompok tidak melakukan interaksi dengan kelompok yang dipandang sebagai kelompok lain atau outgroup, maka kelompok tersebut akan tetap memandang outgroup sebagai ancaman terhadap keberlangsungan kelompoknya dan membuat prasangka semakin kuat.

Pettigrew, Tropp, Wagner, dan Christ (2011) menyatakan, sejalan dengan hipotesis Allport (1954), kontak antarkelompok atau interaksi yang terjalin antara kelompok mayoritas dan minoritas dapat mencegah timbulnya prasangka. Individu yang sering berinteraksi dan terlibat dalam kontak jangka panjang dengan kelompok tertentu memiliki potensi yang lebih tinggi untuk mengurangi prasangka (Pettigrew \& Tropp, 2006; MacInnis \& Page-Gould, 2015). Dhont, Hiel, dan Hewstone (2014) menyatakan bahwa kontak antarkelompok dapat mengurangi efek dari akar-akar ideologis yang melatarbelakangi terjadinya sistem hierarki sosial, yang selanjutnya bisa mengurangi prasangka. Berdasarkan temuan tersebut, kontak antarkelompok dapat diaplikasikan sebagai strategi untuk mereduksi dampak dari keyakinan etnis Sunda yang dipengaruhi oleh faktor sejarah, faktor sosioekonomi, dan faktor lingkungan lainnya terhadap etnis Tionghoa di Bandung.

Mengacu pada paparan di atas, penerapan kontak antarkelompok yang maksimal pada etnis Sunda dan etnis Tionghoa sejalan dengan Peraturan Menteri Dalam Negeri Nomor 34 Tahun 2006 tentang Pedoman Penyelenggaraan Pembauran Kebangsaan di Daerah, yang menganjurkan masyarakat dari berbagai tingkat daerah membentuk forum khusus untuk pembauran etnis (Hudayah \& Winarni, 2014). Di Bandung, salah satu dampak dari kebijakan tersebut dapat dilihat melalui pembauran etnis Tionghoa dan penerimaan kawasan pecinan yang salah satunya bahkan dijadikan sebagai tempat wisata. Akan tetapi, adanya prasangka yang muncul pada etnis Sunda akibat peranan stereotip terhadap etnis Tionghoa (Srisayekti MEDIAPSI | 2020. Vol. 6, No. 2, 145-156 dkk., 2015) secara tidak langsung menggambarkan dampak kebijakan pemerintah yang masih kurang efektif dalam mengatur hubungan antarkelompok di kawasan Bandung.

Beberapa penelitian yang membahas tentang prasangka secara umum mengaitkan munculnya prasangka dengan peranan stereotip yang diyakini oleh individu (Srisayekti dkk., 2015; Himawan, 2020; Pettigrew \& Tropp, 2006). Akan tetapi, ada pula temuan yang mengemukakan bahwa prasangka muncul secara berbeda berdasarkan kondisi atau karakteristik tertentu yang dimiliki individu, seperti usia (Degner \& Wentura, 2010; Gonsalkorale, Sherman, \& Klauer, 2009), jenis kelamin (Ekehammar, Akrami, \& Araya, 2003; Dozo, 2015), dan tingkat pendidikan (Wodtke, 2018; Schaefer, 1996).

Berdasarkan usia, prasangka diprediksi lebih rendah pada anak-anak dan remaja karena kondisi anak-anak dan remaja yang masih berupaya untuk mengeksplorasi lingkungan sekitarnya. Hal ini memengaruhi pengetahuan individu yang masih minim mengenai identitas kelompok dan relasi sosial (Raabe \& Beelmann, 2011; Degner \& Wentura, 2010). Di sisi lain, orang dewasa menengah hingga dewasa akhir cenderung menunjukkan prasangka yang lebih tinggi karena pengaruh fungsi kognitif berupa ketidakmampuan dalam mengoptimalkan selfregulatory, sehingga membuat individu kesulitan mencegah aktivasi stereotip terhadap outgroup (Connelly, Hasher, \& Zacks, 1991; Gonsalkorale dkk., 2009).

Berdasarkan jenis kelamin, secara konsisten hasil penelitian yang telah dilakukan menyatakan bahwa laki-laki menunjukkan prasangka yang lebih besar terhadap outgroup dibandingkan perempuan (Dozo, 2015; Ekehammar dkk., 2003). Salah satu faktor yang mendasari fenomena ini adalah peran gender di lingkungan masyarakat yang cenderung membuat perempuan kurang leluasa dalam mengekspresikan sikapnya terhadap outgroup (Ekehammar dkk., 2003). Sementara itu, lakilaki yang dianggap dominan dan lebih agresif 
membuat mereka lebih bebas dalam mengekspresikan prasangka (Dozo, 2015).

Selanjutnya, tingkat pendidikan turut berpengaruh terhadap pemahaman seseorang mengenai keberagaman etnis yang berpotensi mencegah timbulnya prasangka (Wodtke, 2018; Schaefer, 1996). Tingkat pendidikan yang semakin tinggi menyediakan ilmu pengetahuan yang lebih luas, mencakup sumber sejarah terpercaya terkait keberagaman etnis (Bobo \& Licari, 1989). Penerapan ilmu yang optimal mengenai latar belakang etnis maupun cara berinteraksi dengan kelompok berdampak pada bagaimana seseorang memandang kelompok tertentu (Gordijn, Koomen, \& Stapel, 2001). Semakin dalam pemahaman seseorang tentang keberagaman budaya dan kelompok yang tergabung di dalamnya, maka orang tersebut akan mengembangkan sikap negatif terhadap prasangka (Hyman \& Wright, 1979).

Paparan di atas menunjukkan bahwa kontak antarkelompok dan karakteristik individu yang dikenal dengan istilah variabel atau faktor demografis dalam penelitian sebelumnya berpengaruh terhadap prasangka. Di sisi lain, terdapat temuan yang menyatakan bahwa pengaruh kontak antarkelompok pada sikap individu terhadap outgroup berbeda pada remaja dan orang dewasa (Wolfer, Schmid, Hewstone, \& Zaalk, 2016). Sebagai contoh, hasil penelitian Mahonen, Jasinskaja-Lahti, dan Liebkind (2011) membuktikan adanya perbedaan pengaruh kontak antarkelompok pada sikap individu terhadap outgroup berdasarkan jenis kelamin. Sementara itu, Hewstone dan Swart (2011) menemukan bahwa pengaruh kontak antarkelompok pada sikap terhadap outgroup dipengaruhi oleh faktor empiris yang berkaitan dengan pengetahuan individu, yang bisa diketahui melalui tingkat pendidikan. Temuan yang tidak konsisten terkait pengaruh kontak antarkelompok pada sikap terhadap outgroup mengindikasikan adanya variabel yang dapat memengaruhi arah hubungan antara variabel independen dan variabel dependen. Baron dan Kenny (1986) menyatakan, variabel yang dapat memengaruhi arah dan kekuatan hubungan antara variabel independen dengan variabel dependen disebut variabel moderator.

Atas dasar uraian teoritis dan temuantemuan empiris yang relevan sebagaimana dijabarkan di atas, penelitian ini mengajukan tiga hipotesis. Pertama, kontak antarkelompok berperan signifikan dalam memprediksi prasangka (Hipotesis 1). Kedua, variabel demografi berperan signifikan dalam memprediksi prasangka (Hipotesis 2), Ketiga, variabel demografis berperan signifikan dalam memoderasi hubungan antara kontak antarkelompok dan prasangka (Hipotesis 3).

\section{Metode \\ Partisipan dan desain penelitian}

Total partisipan dalam penelitian ini adalah 384 etnis Sunda yang tinggal di Bandung. Partisipan yang berusia 15-20 tahun berjumlah 194 orang $(50.5 \%)$, yang berusia 21 26 tahun berjumlah 172 orang $(44.8 \%)$, dan yang berusia 27 tahun ke atas berjumlah 18 orang $(4.7 \%)$. Selanjutnya, partisipan terdiri dari 314 orang perempuan $(81.8 \%)$ dan 70 orang laki-laki (18.2\%). Partisipan dengan tingkat pendidikan SD atau SMP dan sederajat berjumlah 34 orang (8.8\%), SMA atau SMK dan sederajat berjumlah 223 orang (58.1\%), dan perguruan tinggi berjumlah 127 orang (33.1\%).

Penelitian ini menggunakan metode kuantitatif dengan desain korelasional untuk mengetahui peran variabel demografis (usia, jenis kelamin, tingkat pendidikan; Z) dalam memoderasi hubungan antara kontak antarkelompok (X) dan prasangka (Y).

\section{Prosedur dan pengukuran}

Instrumen yang digunakan untuk mengukur kontak antarkelompok adalah General Intergroup Contact Quantity and Contact Quality (CQCQ) yang dibuat oleh Islam dan Hewstone (1993). Skala ini terdiri dari 11 aitem dengan koefisien reliabilitas Cronbach alpha $(\alpha)$ sebesar .84. Sementara itu, 
instrumen yang digunakan untuk mengukur prasangka adalah skala Prasangka Sosial terhadap Etnis Tionghoa yang dibuat oleh Rolando (2012), yang terdiri dari 42 aitem dengan koefisien reliabilitas sebesar .96 .

Teknik analisis data menggunakan uji regresi linear untuk mengukur peran kontak antarkelompok dan variabel demografis (usia, jenis kelamin, tingkat pendidikan) terhadap prasangka. Analisis dengan pendekatan moderasi selanjutnya digunakan melalui uji regresi bertingkat (hierarchical regression) (Jose, 2013). Berdasarkan teknik analisis tersebut, terdapat tiga prediktor yang terdiri dari variabel X (kontak antarkelompok), variabel $\mathrm{Z}$ (variabel demografis: jenis kelamin, etnis atau suku bangsa, tingkat pendidikan), dan variabel XZ (perkalian antara kontak antarkelompok dan variabel demografis). Moderasi muncul sebagai produk dari interaksi variabel $\mathrm{X}$ dan $\mathrm{Z}$ dalam memprediksi variabel $\mathrm{Y}$.

Peneliti juga menggunakan metode Moderated Regression Analysis (MRA) untuk menentukan jenis variabel moderator berdasarkan ada atau tidaknya hubungan interaksi antara variabel moderator dengan variabel independen, serta hubungan antara variabel moderator dengan variabel dependen.

\section{Hasil}

Rincian hasil analisis dalam penelitian ini ditampilkan dalam Tabel 1, Tabel 2, dan Tabel 3 di bawah ini.

Sebagaimana bisa dicermati pada Model 1 di dalam masing-masing tabel, kontak antarkelompok memprediksi prasangka secara signifikan ke arah negatif. Hal ini mengandung arti bahwa semakin tinggi kontak antarkelompok maka semakin rendah prasangka. Sebaliknya, semakin rendah kontak antarkelompok berimplikasi pada semkain tingginya prasangka. Persentase kontak antarkelompok dalam menjelaskan variansi prasangka adalah sebesar $27 \%$, sebagaimana bisa dilihat pada nilai $R^{2}$ dalam model 1 pada Tabel 1, Tabel 2, dan Tabel 3. Temuan ini dengan demikian mendukung Hipotesis 1.

Tabel 1. Peran Usia dalam Memoderasi Hubungan antara Kontak Antarkelompok dan Prasangka

\begin{tabular}{|c|c|c|c|c|c|c|}
\hline & Model & $B$ & $\beta$ & $t$ & $p$ & $R^{2}$ \\
\hline \multirow[t]{3}{*}{1} & $($ Constant $)$ & 134.57 & - & 26.49 & $<.001$ & \multirow{3}{*}{.27} \\
\hline & Kontak & & & & & \\
\hline & $\begin{array}{l}\text { Antarkelom } \\
\text { pok }\end{array}$ & -1.86 & -.515 & -11.74 & $<.001$ & \\
\hline \multirow[t]{4}{*}{2} & (Constant) & 128.01 & - & 22.06 & $<.001$ & \multirow{4}{*}{.28} \\
\hline & Kontak & & & & & \\
\hline & $\begin{array}{l}\text { Antarkelom } \\
\text { pok }\end{array}$ & -1.841 & -.511 & -11.72 & $<.001$ & \\
\hline & Usia & 3.99 & .10 & 2.30 & .022 & \\
\hline \multirow[t]{5}{*}{3} & (Constant) & 130.43 & - & 8.93 & $<.001$ & \multirow{5}{*}{.28} \\
\hline & Kontak & & & & & \\
\hline & $\begin{array}{l}\text { Antarkelom } \\
\text { pok }\end{array}$ & -1.92 & -.53 & -4.22 & $<.001$ & \\
\hline & Usia & 2.48 & .06 & 0.29 & .77 & \\
\hline & KA*US & 0.05 & .04 & 0.18 & .86 & \\
\hline
\end{tabular}
terstandarisasi; KA*US = perkalian antara kontak antarkelompok dan usia

Tabel 2. Peran Jenis Kelamin dalam Memoderasi Hubungan antara Kontak Antarkelompok dan Prasangka

\begin{tabular}{|c|c|c|c|c|c|c|}
\hline & Model & $B$ & $\beta$ & $t$ & $p$ & $R^{2}$ \\
\hline \multirow[t]{3}{*}{1} & $($ Constant $)$ & 134.57 & - & 26.49 & $<.001$ & \multirow{3}{*}{.27} \\
\hline & Kontak & & & & & \\
\hline & $\begin{array}{l}\text { Antarkelom } \\
\text { pok }\end{array}$ & -1.86 & -0.52 & -11.74 & 0.000 & \\
\hline \multirow[t]{5}{*}{2} & (Constant) & 132.96 & - & 25.95 & $<.001$ & \multirow{5}{*}{.27} \\
\hline & Kontak & & & & & \\
\hline & Antarkelom & -1.83 & -0.51 & -11.64 & $<.001$ & \\
\hline & $\begin{array}{l}\text { pok } \\
\text { Jenis }\end{array}$ & & & & & \\
\hline & $\begin{array}{l}\text { Jenis } \\
\text { Kelamin }\end{array}$ & 5.31 & 0.09 & 2.02 & 0.044 & \\
\hline \multirow[t]{6}{*}{3} & (Constant) & 132.99 & - & 23.20 & $<.001$ & \multirow{6}{*}{.27} \\
\hline & Kontak & & & & & \\
\hline & Antarkelom & -1.84 & -0.51 & -10.36 & $<.001$ & \\
\hline & pok & & & & & \\
\hline & $\begin{array}{l}\text { Jenis } \\
\text { Kelamin }\end{array}$ & 5.16 & 0.09 & 0.42 & 0.675 & \\
\hline & KA*JK & 0.01 & 0.00 & 0.01 & 0.990 & \\
\hline
\end{tabular}

Sementara itu, variabel demografis jenis kelamin terbukti signifikan dalam memprediksi ke arah positif prasangka, sebagaimana bisa dilihat pada Model 2 dalam Tabel 2. Temuan ini bermakna bahwa laki-laki dibandingkan perempuan menunjukkan prasangka yang lebih tinggi terhadap etnis Tionghoa. Usia juga 
menunjukkan peran yang sama, yang mencerminkan bahwa bertambahnya usia berimplikasi pada bertambahnya prasangka. Sementara itu, tingkat pendidikan tidak terbukti signifikan dalam memprediksi prasangka, sebagaimana bisa dilihat pada Model 2 dalam Tabel 3. Temuan-temuan ini dengan demikian mendukung secara sebagian Hipotesis 2.

Tabel 3. Peran Tingkat Pendidikan dalam Memoderasi Hubungan antara Kontak Antarkelompok dan Prasangka

\begin{tabular}{|c|c|c|c|c|c|c|}
\hline & Model & $B$ & $\beta$ & $t$ & $p$ & $R^{2}$ \\
\hline \multirow[t]{3}{*}{$\overline{1}$} & (Constant) & 134.57 & - & 26.49 & $<.001$ & \multirow{3}{*}{.27} \\
\hline & Kontak & & & & & \\
\hline & $\begin{array}{l}\text { Antarkelom } \\
\text { pok }\end{array}$ & -1.86 & -0.52 & -11.74 & 0.000 & \\
\hline \multirow[t]{4}{*}{2} & (Constant) & 139.34 & - & 22.78 & $<.001$ & \multirow{4}{*}{.27} \\
\hline & Kontak & & & & & \\
\hline & Antarkelom & -1.87 & -0.52 & -11.83 & $<.001$ & \\
\hline & $\begin{array}{l}\text { Tingkat } \\
\text { Pendidikan }\end{array}$ & -2.37 & -0.06 & -1.40 & 0.164 & \\
\hline \multirow[t]{6}{*}{3} & (Constant) & 143.73 & - & 9.20 & $<.001$ & \multirow{6}{*}{.27} \\
\hline & Kontak & & & & & \\
\hline & Antarkelom & -2.01 & -0.56 & -4.16 & $<.001$ & \\
\hline & pok & & & & & \\
\hline & $\begin{array}{l}\text { Tingkat } \\
\text { Pendidikan }\end{array}$ & -4.96 & -0.13 & -0.57 & 0.566 & \\
\hline & $\mathrm{KA} * \mathrm{TP}$ & 0.08 & 0.08 & 0.31 & 0.760 & \\
\hline
\end{tabular}

Hasil terakhir menunjukkan bahwa, sebagaimana bisa dilihat pada Model 3 dalam Tabel 1, Tabel 2, dan Tabel 3 secara berturutturut, interaksi antara usia, jenis kelamin, dan tingkat pendidikan dengan kontak antarkelompok terbukti tidak signifikan dalam menjelaskan atau memprediksi prasangka terhadap etnis Tionghoa. Implikasinya, Hipotesis 3 dalam penelitian ini ditolak.

\section{Diskusi}

Penelitian ini bertujuan untuk menguji sejauh mana kontak antarkelompok, faktor demografis (jenis kelamin, usia, dan tingkat pendidikan) serta interaksi antara kedua variabel ini berperan dalam memprediksi prasangka terhadap etnis Tionghoa. Hasil penelitian ini menunjukkan bahwa kontak MEDIAPSI | 2020. Vol. 6, No. 2, 145-156 antarkelompok berkorelasi signifikan ke arah positif dengan prasangka etnis Sunda terhadap etnis Tionghoa di Bandung. Temuan ini menggambarkan integrasi dari kuantitas serta kualitas interaksi antara etnis Sunda dan etnis Tionghoa berdasarkan sudut pandang etnis Sunda sebagai kelompok mayoritas di Bandung. Pengaruh kontak antarkelompok terhadap prasangka etnis Sunda pada etnis Tionghoa termasuk pengaruh negatif, artinya semakin tinggi kontak yang terjalin antara etnis Sunda dan etnis Tionghoa, maka semakin rendah prasangka etnis Sunda terhadap etnis Tionghoa.

Temuan di atas selaras dengan hasil penelitian MacInnis dan Page-Gould (2015), yang melaporkan bahwa individu yang sering berinteraksi dan terlibat dalam kontak jangka panjang dengan kelompok tertentu menunjukkan prasangka yang rendah terhadap kelompok tersebut. Selain itu, Dhont dkk. (2014) mengemukakan bahwa kontak yang terjalin antarkelompok berperan sebagai faktor yang mereduksi dukungan terhadap ideologi yang menekankan sistem hirarki sosial. Peran ini membuat kontak antarkelompok bisa menekan prasangka antarkelompok. Selain itu, adanya kontak yang tinggi antarkelompok dapat meningkatkan pengetahuan tentang outgroup sehingga stereotip negatif mengenai kelompok tersebut dapat dihindari (Allport, 1954).

Penerapan kontak antarkelompok yang maksimal di antara etnis Sunda dan etnis Tionghoa dapat menjadi bahan pertimbangan pemerintah dalam membuat kebijakan untuk, pertama, memperkuat jaminan penerimaan etnis Tionghoa sebagai warga negara Indonesia. Kedua, kebijakan pemerintah yang bertujuan untuk mencegah dan mengurangi diskriminasi dalam bentuk apapun terhadap etnis Tionghoa, seperti kebebasan beragama dan mengekspresikan kekayaan budaya. Kebijakan tersebut sejatinya telah diwujudkan di beberapa daerah di Bandung, seperti penerimaan kawasan pecinan dan diskusi-diskusi terbuka untuk memberi kesempatan pada warga 
Bandung agar dapat berinteraksi langsung dengan etnis Tionghoa (Tuosikal, 2018). Namun, kegiatan-kegiatan tersebut baru dilakukan di daerah pusat kota Bandung, belum menyebar secara menyeluruh ke wilayah Bandung lainnya. Hal ini perlu dijadikan perhatian, baik bagi etnis Sunda maupun etnis Tionghoa karena populasi etnis Tionghoa di Bandung tidak hanya berpusat pada satu titik saja.

Selanjutnya, terdapat korelasi yang signifikan antara usia dengan prasangka etnis Sunda pada etnis Tionghoa di Bandung. Temuan ini menjelaskan perbedaan prasangka yang muncul pada remaja, dewasa awal, dan dewasa menengah. Priest dkk. (2018) dalam penelitiannya mengemukakan bahwa remaja cenderung memiliki prasangka yang lebih rendah dibandingkan orang dewasa karena remaja masih berada dalam tahap eksplorasi. Dalam tahap eksplorasi ini, remaja masih berupaya untuk mempelajari apa yang terdapat di lingkungannya. Degner dan Wentura (2010) menjelaskan bahwa aktivasi prasangka secara otomatis pada masa remaja awal disebabkan oleh fungsi kognitif yang membuat remaja mulai menyadari identitas sosial dan kaitannya dengan berbagai macam etnis dalam struktur sosial. Dalam hal memahami identitasnya sendiri berdasarkan ras, etnis, dan lain sebagainya, remaja perlu belajar tentang keberadaan etnis lainnya sehingga kondisi demikian memengaruhi bagaimana remaja memandang etnis lain sebagai outgroup. Pengetahuan mengenai outgroup pada masa remaja dapat dipengaruhi oleh orang tua dan keluarga (Harmaini, 2019), kelompok teman sebaya (Benner, Crosnoe, \& Eccles, 2014), dan orang dewasa yang berada di lingkungan sekitarnya (Priest, dkk., 2018).

Melalui temuan tersebut, keluarga, khususnya orang tua, dianjurkan untuk mengawasi perkembangan anaknya terkait pembentukan relasi sosial di lingkungan sekitar. Selain itu, orang tua dapat membimbing anaknya untuk mengembangkan sikap positif demi menjaga kerukunan dengan etnis Tionghoa maupun etnis-etnis lainnya. Hal tersebut didukung oleh hasil penelitian Harmaini (2019), yang menunjukkan bahwa orang tua berperan penting dalam mengajarkan nilai-nilai positif mengenai outgroup.

Pada dewasa menengah dan dewasa akhir, munculnya prasangka disebabkan oleh kemunduran kognitif yang mengakibatkan individu gagal dalam mengoptimalkan selfregulatory sehingga individu tidak dapat menekan stereotip negatif terhadap outgroup (Connelly dkk., 1991). Ketidakmampuan dalam mengoptimalkan self-regulatory membuat orang dewasa yang lebih tua cenderung lebih rentan mengekspresikan sikap negatifnya terhadap outgroup (Gonsalkorale dkk., 2009). Walaupun demikian, penentuan perspektif pada orang lanjut usia dapat membantu mengurangi prasangka dan memengaruhi pandangannya terhadap kelompok ingroup dan outgroup. Penentuan perspektif membantu lansia dalam mengasah empati, sehingga lansia dapat memposisikan diri sebagai kelompok yang dijadikan objek prasangka (Castilloa, Equizábal, Cámara, \& González, 2014).

Temuan lain dalam penelitian ini terkait dengan adanya korelasi yang signifikan antara jenis kelamin dan prasangka etnis Sunda pada etnis Tionghoa di Bandung. Perbedaan pengaruh jenis kelamin menunjukkan bahwa laki-laki cenderung memiliki prasangka yang lebih besar terhadap etnis Tionghoa dibandingkan perempuan. Sejalan dengan penelitian sebelumnya, secara eksplisit, terdapat kecenderungan yang lebih besar pada laki-laki dalam mengekspresikan prasangka terhadap outgroup dibandingkan perempuan (Akrami, Ekehammar, \& Araya, 2000; Ekehammar dkk., 2003; Dozo, 2015). Temuan ini menggambarkan adanya perbedaan peran dan status di lingkungan sosial yang memengaruhi persepsi dan sikap antara laki-laki dan perempuan dalam menghadapi isu keragaman budaya di Bandung.

Laki-laki yang dikenal memiliki sifat 
lebih dominan dan agresif menjadi faktor yang melatarbelakangi kecenderungannya dalam mengekspresikan prasangka. Sementara itu, secara alami perempuan memiliki sifat yang lebih emosional serta empati yang lebih besar, sehingga hal tersebut memengaruhi caranya dalam mengatur prasangka (Dozo, 2015). Ekehammar dkk. (2003) mengemukakan, perempuan memiliki keterbatasan dalam mengekspresikan sikap negatifnya terhadap outgroup karena peranan stereotip yang berlaku dalam lingkungan masyarakat.

Secara umum, temuan dalam penelitian ini dapat dijadikan antisipasi terhadap pembenaran stereotip yang mengatakan bahwa, sikap laki-laki yang lebih dominan dan agresif membuat laki-laki cenderung lebih leluasa dalam mengekspresikan prasangkanya terhadap etnis Tionghoa. Worchel, Axsom, Ferris, Samaha, dan Schweitzer (1978) menyatakan bahwa prasangka dianggap sebagai sifat negatif yang tidak dapat dibenarkan terhadap suatu kelompok dan anggotanya. Oleh karena itu, terlepas dari jenis kelamin individu, prasangka tetap perlu dihindari demi menjaga stabilitas hubungan yang baik antaretnis.

Hasil lainnya menunjukkan bahwa tingkat pendidikan tidak berkorelasi secara signifikan dengan prasangka etnis Sunda pada etnis Tionghoa di Bandung. Hal ini berbanding terbalik dengan penelitian-penelitian sebelumnya yang mengatakan bahwa pendidikan memengaruhi kecenderungan individu dalam berprasangka. Individu dengan tingkat pendidikan lebih tinggi cenderung menunjukkan prasangka yang lebih rendah dan sebaliknya (Wodtke, 2018; Wodtke, 2012; Gordijn dkk., 2001; Schaefer, 1996). Hasil penelitian Wodtke (2012) membuktikan bahwa peran pendidikan dalam memengaruhi kecenderungan seseorang untuk menolak stereotip yang mengarah pada suatu kelompok bergantung pada kondisi lingkungan tertentu. Harmaini (2019) menjelaskan bahwa orang tua dan keluarga berperan penting dalam menyampaikan nilai-nilai yang berkaitan dengan outgroup sehingga hal tersebut ikut andil dalam memengaruhi prasangka individu di luar lingkungan akademik.

Hasil-hasil dalam penelitian ini dapat dijadikan sebagai acuan bahwa sistem pendidikan di Indonesia, khususnya di Bandung, masih belum efektif dalam menyampaikan nilai-nilai moral terkait relasi antaretnis dan sikap yang perlu dikembangkan untuk menghindari prasangka. Penerapan ilmu yang tidak optimal tentang keberagaman budaya dan kelompok yang tergabung di dalamnya berpotensi membiarkan stereotip yang ada bertahan (Wodtke, 2018; Hyman \& Wright, 1979). Sejalan dengan upaya mewujudkan pendidikan multikultural di Indonesia sebagaimana telah dikemukakan oleh Afandi (2018), dalam melawan prasangka dan diskriminasi, diperlukan strategi untuk menyusun sistem pendidikan yang efektif dan berlaku bagi seluruh etnis di setiap daerah. Selain itu, untuk mengurangi prasangka, sistem pendidikan multikultural hendaknya mampu memberi pemahaman agar masyarakat tidak lagi mengacu pada dominansi kelompok terhadap kelompok lain.

Penelitian ini mengandung sejumlah keterbatasn, yang bisa disempurnakan pada studi-studi lanjutan. Pertama, pengumpulan data hanya dilakukan secara online karena masa pandemi COVID-19 masih berlangsung. Untuk menutupi kekurangan ini, jika masa pandemi COVID-19 sudah berakhir, studi lanjutan bisa memperluas target responden dengan melibatkan orang dewasa akhir atau lanjut usia untuk mendapat gambaran yang lebih komprehensif mengenai pengaruh usia terhadap prasangka. Kedua, peneliti hanya berfokus pada etnis Sunda sebagai subjek utama untuk mendapat gambaran interaksi sosial dengan etnis Tionghoa di Bandung. Untuk menutupi kekurangan ini, studi lanjutan bisa berfokus pada etnis lain yang tinggal di Bandung atau menjadikan etnis Tionghoa sebagai subjek utama guna mendapatkan perspektif yang berbeda dalam kaitannya dengan prasangka. 


\section{Daftar Pustaka}

Adelina, F. (2017). Hubungan antara prasangka sosial dan intensi melakukan diskriminasi mahasiswa etnis Jawa terhadap mahasiswa yang berasal dari Nusa Tenggara Timur. Jurnal Sains Psikologi, 6(1), http://dx.doi.org//10.17997/um023v6i12 $017 \mathrm{p} 001$

Afandi. (2018). Mewujudkan pendidikan multikultural di Indonesia (Sebuah kajian pendidikan multikultural di berbagai negara). Wawasan Makro Pendidikan, 1-9. Diakses dari https://www.researchgate.net/publicatio n/328491646_MEWUJUDKAN_PEND IDIKAN_MULTIKULTURAL_DI_IN DONESIA_SEBUAH_KAJIAN_PEND IDIKAN_MULTIKULTURAL_DI_BE RBAGAI_NEGARA?channel=doi\&link $\mathrm{Id}=5$ bd0ac60a6fdcc6f790002b0\&showF ulltext=true

Akrami, N., Ekehammar, B., \& Araya, T. (2000). Classical and modern racial prejudice: A study of attitudes toward immigrants in Sweden. European Journal of Social Psychology,30(4), 521-532. https://doi.org/10.1002/10990992(200007/08)30:4\%3C521::AIDEJSP5\%3E3.0.CO;2-N

Allport, G. W. (1954). The Nature of prejudice. Massachusetts: Addison-Wesley Publishing Company.

Baron, R. M., \& Kenny, D. A. (1986). The moderator-mediator variable distinction in social psychological research: Conceptual, strategic, and statistical considerations. Journal of Personality and Social Psychology, 51(6), 11731182. DOI: $\quad 10.1037 / / 0022-$ 3514.51.6.1173

Benner, A. D., Crosnoe, R., \& Eccles, J. S. (2015). Schools, peers, and prejudice in adolescence. Journal of research on adolescence, 25(1), 173-188. https://doi.org/10.1111/jora.12106
Bobo, L., \& Licari, F. C. (1989). Education and political tolerance: Testing the effects of cognitive sophistication and target group affect. Public Opinion Quarterly, 53(3), 285-308. https://doi.org/10.1086/269154

Burhan, O. K., \& Sani, J. (2013). Prasangka terhadap etnis Tionghoa di Kota Medan: Peran Identitas nasional dan persepsi ancaman. Psikologia: Journal Pemikirian dan Penelitian Psikologi, 8(1), 25-33. https://doi.org/10.32734/psikologia.v8i1 .2562

Castillo, J. L. Á., Equizábal, A. J., Cámara, C. P., \& González, H. G. (2014). The fight against prejudice in older adults: Perspective taking effectiveness. Revista Latinoamericana de Psicología, 46(3), 137-147. https://doi.org/10.1016/S01200534(14)70017-2

Cohrs, J. C., \& Duckitt, J. (2012). Prejudice, types, and origins of. In D. J. Christie (Ed.), The encyclopedia of peace psychology (pp. 1-7). UK: WileyBlackwell.

https://doi.org/10.1002/9780470672532.w bepp 218

Connelly, S. L., Hasher, L., \& Zacks, R. T. (1991). Age and reading: The impact of distraction. Psychology and Aging, 6(4), 533. https://doi.org/10.1037//08827974.6.4.533

Coppel, C. A. (2003). Kendala-kendala sejarah dalam penerimaan etnis Cina di Indonesia yang multikultural. Antropologi Indonesia, 71, 13-20. https://doi.org/10.7454/ai.v0i71.3465

Degner, J., \& Wentura, D. (2010). Automatic prejudice in childhood and early adolescence. Journal of Personality and Social Psychology, 98(3), 356-374. DOI: $10.1037 / \mathrm{a} 0017993$

Dhani, A. (2016, September 1). Sejarah kebencian terhadap etnis Tionghoa. Tirto.id. Diambil dari 
:https://tirto.id/sejarah-kebencianterhadap-etnis-tionghoa-bFLp

Dhont, K., Van Hiel, A., \& Hewstone, M. (2014). Changing the ideological roots of prejudice: Longitudinal effects of ethnic intergroup contact on social dominance orientation. Group Processes \& Intergroup Relations, 17(1), 27-44. https://doi.org/10.1177\%2F1368430213 497064

Dozo, N. (2015). Gender differences in prejudice: A biological and social psychological analysis $(\mathrm{PhD}$ thesis, School of Psychology, The University of

Queensland). https://doi.org/10.14264/uql.2015.777

Ekehammar, B., Akrami, N., \& Araya, T. (2003). Gender differences in implicit prejudice. Personality and Individual differences, 34(8), 1509-1523. https://doi.org/10.1016/S01918869(02)00132-0

Gonsalkorale, K., Sherman, J. W., \& Klauer, K. C. (2009). Aging and prejudice: Diminished regulation of automatic race bias among older adults. Journal of Experimental Social Psychology, 45(2), 410-414.

https://doi.org/10.1016/j.jesp.2008.11.0 04

Gordijn, E. H., Koomen, W., \& Stapel, D. A. (2001). Level of prejudice in relation to knowledge of cultural stereotypes. Journal of Experimental Social Psychology, 37(2), 150-157. https://doi.org/10.1006/jesp.2000.1443

Harmaini, S. M. (2019). Prasangka etnik Melayu terhadap etnik Minangkabau. Makna: Jurnal Kajian Komunikasi, Bahasa, dan Budaya, 4(1), 20-31. Diakses dari http://jurnal.unismabekasi.ac.id/index.p hp/makna/article/view/1670/1440

Hewstone, M., \& Swart, H. (2011). Fifty-odd years of inter-group contact: From hypothesis to integrated theory. British Journal of Social Psychology, 50(3), 374-386. https://doi.org/10.1111/j.20448309.2011.02047.x

Himawan, E. M. (2020, Mei 20). 22 tahun Setelah kerusuhan anti-Cina Mei 1998, riset ungkap prasangka dan trauma masih ada. The Conversation. Diambildari

https://theconversation.com/22-tahunsetelah-kerusuhan-anti-cina-mei-1998riset-ungkap-prasangka-dan-traumamasih-ada-138962

Hudayah, N., \& Winarni, R. (2014). Pengaruh kebijakan pemerintah Indonesia terhadap kehidupan etnis Tionghoa di bidang politik, sosial budaya, dan ekonomi di Kabupaten Jember dari zaman orde lama sampai zaman reformasi pada tahun 1998-2012. Publika Udaya, 2(2), 19-31. Diakses dari

https://jurnal.unej.ac.id/index.php/PB/ar ticle/view/1506/1235

Hyman, H. H., \& Wright, C. R. (1979). Education's lasting influence on values. Chicago: University of Chicago Press.

Ikasari, P. N. (2017). Perempuan dalam diskriminasi etnis di Indonesia (Analisis Film Sapu Tangan Fang Yin). Jurnal Komunikasi dan Kajian Media, 1(1), 5768. DOI: $10.31002 / j k k m . v 1 i 1.391$

Islam, M. R., \& Hewstone, M. (1993). Dimensions of contact as predictors of intergroup anxiety, perceived out-group variability, and out-group attitude: An integrative model. Personality and Social Psychology Bulletin, 19(6), 700-710. https://doi.org/10.1177\%2F01461672931 96005

Isnaeni, H. F. (2019). Duka warga Tionghoa. Historia. Diakses dari https://historia.id/politik/articles/dukawarga-tionghoa-DbKmv 
Jose, P. E. (2013). Doing statistical mediation $\&$ moderation. New York: The Guilford Press.

Kustedja, S. (2012). Jejak komunitas Tionghoa dan perkembangan Kota Bandung. Jurnal Sosioteknologi, 11(26), 105-128. Diakses dari

http://journals.itb.ac.id/index.php/sostek/a rticle/view/1095

Lestari, S. (2018, Mei 16). Kerusuhan Mei 1998: "Apa salah kami sampai (diancam) mau dibakar dan dibunuh?". NewsBbc. Diakses dari https://www.bbc.com/indonesia/indonesia $-43940188$

MacInnis, C. C., \& Page-Gould, E. (2015). How can intergroup interaction be bad if intergroup contact is good? Exploring and reconciling an apparent paradox in the science of intergroup relations. Perspectives on Psychological Science, 10(3), 307-327. https://doi.org/10.1177\%2F17456916145 68482

Mähönen, T. A., Jasinskaja-Lahti, I., \& Liebkind, K. (2011). The impact of perceived social norms, gender, and intergroup anxiety on the relationship between intergroup contact and ethnic attitudes of adolescents. Journal of Applied Social Psychology, 41(8), 18771899. https://doi.org/10.1111/j.15591816.2011.00793.x

Melissa, E. (2013). Representasi Warga Tionghoa dan Kecinaan dalam Media Kontemporer Indonesia. Jurnal Komunikasi Indonesia, 2(1), 15-22. https://doi.org/10.7454/jki.v2i1.7826

Muhammad, M., \& Larasati, U. (2017). Kerusuhan rasial di Bandung 5 Agustus 1973. Bekasi: Kipas.

Pettigrew, T. F., \& Tropp, L. R. (2006). A meta-analytic test of intergroup contact theory. Journal of Personality and Social Psychology, 90(5), 751-783.
Pettigrew, T. F., Tropp, L. R., Wagner, U., \& Christ, O. (2011). Recent advances in intergroup contact theory. International Journal of Intercultural Relations, 35(3), 271-280. https://doi.org/10.1016/j.ijintrel.2011.03.0 01

Priest, N., Slopen, N., Woolford, S., Phillip, J. T., Singer, D., Kauffman, A. D., . . . Williams, D. (2018). Stereotyping across intersections of race and age: Racial stereotyping among White adults working with children. Plos One, 13(9), 1-20. https://doi.org/10.1371/journal.pone.0201 696

Raabe, T., \& Beelmann, A. (2011). Development of ethnic, racial, and national prejudice in childhood and adolescence: A multinational meta-analysis of age differences. Child Development, 82(6), 1715-1737. https://doi.org/10.1111/j.14678624.2011.01668.x

Rolando, R. (2012). Perbandingan prasangka sosial mahasiswa etnis Sunda, Jawa, Batak, dan Minang terhadap masyarakat etnis Tionghoa di Kota Bandung. (Skripsi tidak dipublikasikan). Universitas Pendidikan Indonesia, Bandung, Indonesia.

Sawyer, P. J., Major, B., Casad, B. J., Townsend, S. S., \& Mendes, W. B. (2012). Discrimination and the stress response: Psychological and physiological consequences of anticipating prejudice in interethnic interactions. American Journal of Public Health, 102(5), 1020-1026. Diakses dari https://ajph.aphapublications.org/doi/pdfp lus/10.2105/AJPH.2011.300620

Schaefer, R. T. (1996). Presidential address education and prejudice: Unraveling the relationship. The Sociological Quarterly, 37(1), 1-16. https://doi.org/10.1111/j.15338525.1996.tb02328.x 
Schütz, H., \& Six, B. (1996). How strong is the relationship between prejudice and discrimination? A meta-analytic answer. International Journal of Intercultural Relations, 20(3-4), 441-462. https://doi.org/10.1016/01471767(96)00028-4

Sjafari, I. (2018, Mei 10). Kerusuhan rasial 10 Mei 1963, Analisa awal. Kompasiana. Diakses dari: https://www.kompasiana.com/jurnalgemi ni/5af44ea3ab12ae1b60255b64/kerusuhan -rasial-10-mei-1963-analisaawal?page $=$ all

Sjamsuddin, H. (2002). Rusuh di Bandung: Peristiwa 5 Agustus 1973 dalam liputan media massa. Historia: Jurnal Pendidikan Sejarah, 6(3), 1-10. Diakses dari

http://sejarah.upi.edu/artikel/dosen/rusuhdi-bandung-peristiwa-5-agustus-1973dalam-liputan-media-massa/

Srisayekti, W., Setiady, D. A., \& Sanitioso, R. B. (2015). Harga diri (self-esteem) terancam dan perilaku menghindar. Jurnal Psikologi, 42(2), 141-156. Diakses dari https://www.neliti.com/publications/1267 79/harga-diri-self-esteem-terancam-danperilaku-menghindar\#cite

Suryadinata, L. (2003). Kebijakan Negara Indonesia terhadap etnik Tionghoa: Dari asimilasi ke multikulturalisme? Antropologi Indonesia, 71, 1-12. https://doi.org/10.7454/ai.v0i71.3464

Tropp, L. R. (2003). The psychological impact of prejudice: Implications for intergroup contact. Group Processes \& Intergroup Relations, 6(2), 131-149. https://doi.org/10.1177\%2F13684302030 06002001

Tuosikal, R. (2018, Desember 6). Membuka "ruang perjumpaan" Tionghoa dan etnis lain.Voa Indonesia. Diambil dari https://www.voaindonesia.com/a/membuk a-ruang-perjumpaan-tionghoa-dan-etnislain/4689060.html

Wigarani, L., Bain, \& Witasari, N. (2019). Kerusuhan anti Tionghoa di Semarang tahun 1980. Journal of Indonesian History, $\quad 8(2), \quad 113-120$. https://doi.org/10.15294/jih.v8i2.36974

Wodtke, G. T. (2012). The impact of education on intergroup attitudes: A multiracial analysis. Social

Psychology

Quarterly, 75(1), 80-106. https://doi.org/10.1177\%2F01902725114 30234

Wodtke, G. T. (2018). The effects of education on beliefs about racial inequality. Social Psychology Quarterly, 81(4), 273-294. https://doi.org/10.1177\%2F01902725188 04145

Wölfer, R., Schmid, K., Hewstone, M., \& van Zalk, M. (2016). Developmental dynamics of intergroup contact and intergroup attitudes: Long-term effects in adolescence and early adulthood. Child Development, 87(5), 1466-1478. https://doi.org/10.1111/cdev.12598

Worchel, S., Axsom, D., Ferris, F., Samaha, G., \& Schweizer, S. (1978). Determinants of the effect of intergroup cooperation on intergroup attraction. Journal of Conflict Resolution, 22(3),

429-439. https://doi.org/10.1177\%2F00220027780 2200304 